\title{
Stress Coping Attitudes Based on Perceived Religiousness and Received Religious Education*
}

\author{
Erkan Kavas \\ Department of Social Work, F.E.A.S., Süleyman Demirel Üniversity, Isparta, Turkey \\ Email: drerkankavas@gmail.com
}

Received 26 January 2016; accepted 25 March 2016; published 28 March 2016

Copyright (C) 2016 by author and Scientific Research Publishing Inc.

This work is licensed under the Creative Commons Attribution International License (CC BY). http://creativecommons.org/licenses/by/4.0/

\section{c) (7) Open Access}

\begin{abstract}
This study was carried out to determine whether stress coping attitudes (SCA) change according to age, gender, education, income status, level of religious knowledge, perceived religiousness and the resources where the individuals rooted their religious educations. The study was conducted on 869 participants, aged 15 and over, living in Denizli province. As the data collection tool "Stress Coping Inventory" was used and for demographic information of the participants, "Personal Information form" was used. Stress coping attitudes: it has been found that stress coping attitudes do not vary according to their gender and where they received their religious education whether from Quran Course, in the family, from a Mousque Teacher, at the course of Teaching Religion Moral, Religious Vocational High School and/or from other sources of religious education but they vary according to Age, Education, Religious Knowledge, Perceived Level of Religiosity, Religious Education and Religious Education received from Religious Books.
\end{abstract}

\section{Keywords}

Perceived Religiousness, Stress, Coping with Stress and Attitudes

\section{Introduction}

Lazarus (1999) defines stress as a worrisome and threatening feeling that results from situations or interpretations that we think that we cannot deal with through our own pyschological resources. In other words, stress is a situation that occurs when the organisms' physical and mental limits are pushed and/or threatened (Batlaş, 2010).

\footnotetext{
*This article was adapted from my Ph.D. dissertation "The relation between religious attitude and Coping with Stress” conducted in 2013, at the Institute of Social Sciences at S.D.U.
} 
In the face of force and threats, the organism develops a kind of response chain to defend itself. When the organism encounters a danger, it tries to move away from the threat that the organism thinks that it cannot cope with. However, when the organism believes that it can cope with the threat, it struggles with it and adjusts to the new situation. In the course of stress, when the organism feels threatened, it experiences a set of both physiological and psychological changes (Baltaş \& Baltaş, 2008).

Stress response occurs not based on the situation in the environment but based on how the individual responses to the situation. Our feelings are actually parallel with our thoughts. For this reason, stress occurs with the interaction of certain people with certain events. That is, event is not a determiner itself (Baltaş \& Baltaş, 2008). For instance, while some of them may be stress factors for some people, they may be exciting and interesting for others. Encountering physical difficulties makes car racers and mountain climbers stronger. While some people find it exciting and enjoying to sail in a bad weather or participating in a rescue team, some others might like to work at high buildings, on roofs. In other words, something that is a cause of stress for someone might be a source of happiness for others (Wilkinson, 2005). The meanings that we attach to the events and reasons of stress are much more important (Tutar, 2000). That is, stress might be resulted from our personal inclinations. Whether we will face stress or not because of any event is related to how we perceive that situation. If we consider a negative situation not as a threat but an obstacle to overcome, we can achieve to have less stress (Braham, 2004).

Researchers have made a classification by observing whether the individual tries to cope with the problem itself or with their emotional reactions to the problem (Lazarus \& Folkman, 1984; cited in Burger, 2006). Folkman and Lazarus (1980) asked men and women at the ages of 45 and 65 years old about how they coped with some of the problems they faced in the last seven months and subjects chose the strategies they used from the list provided by the researchers. Over 1300 stressful events were analysed and the results showed that in the $98 \%$ of the events, participants were found to prefer using either emotion based strategies, problem focused strategies or both. This study shows that these two classifications (emotion focused and problem focused strategies) cover most of the methods that people use to cope with their concerns. In another study, it was found that women use emotion focused strategies more than men but the possibility of the solution through men's direct problem solving strategies is higher than women (Burger, 2006).

Studies in the field clearly put forward that there are clear differences between stress reactions of women and men, and that these differences are seen more clearly at the childhood (Baltaş \& Baltaş 2008). Women experience more stressful events and have more depression, anxiety and psychosomatic problem symptoms than men.

This difference may result from the fact that women are more responsive and more sensitive to the emotional events and this is probably because men are often made used to smile and endure in the society (etc. boys don't cry) (Plotnik, 2009).

Stress may occur because of the traumatic events like earthquake, flood, war, fire, severe illness or death, major events like marriage, divorce, commit a crime, imprisonment, lost and debate, daily troubles like finishing a job on time, exams, and time constraints (Hökelekli, 2008). In general, sources of stress can be grouped into two; individual stressors and environmental stressors.

Today, stressors caused by person's environment are increasing as a result of the process of changes and developments around. It is possible to summarize environmental stressors as economic conditions, uncertainty in political life, technological change and uncertainty, physical environmental conditions, social environment conditions and socio-cultural changes (Aydın \& Örnek, 2006).

Individual stressors can also be related to the person's physiological or biological features. There might be biological stressors that occur related to various different systematic disorders, physiological illnesses, glandular and hormonal balance disorders that the individuals have (Tutar, 2000). Individuals' reactions may change according to some variables as people's age, status in the society, education, and economic status. Personality traits such as optimism or pessimism, self-confidence, focus of control are also effective in this respect (Hökelekli, 2008).

In this study, the question of whether stress coping attitudes change according to gender, age, education level, income level, religious knowledge, perceived level of piety and where they receive religious education or not was investigated.

\subsection{Coping with Stress and Religion}

A person who thinks that his/her capacity is not sufficient enough to cope with challenges develops stress. That 
is, if there is a difference between the situation that the person wants to handle and how s/he perceives the situation, stress occurs. However, we are responsible for our own perceptions. If we can't change the situation, then we need to change our perspective about the situation and the way of handling the problem. Anxiety's turning into a chronic state and as a result, stress, does not let person gain a new perspective to the problems he/she has; on the contrary, it stalemates the person. High anxiety level causes the person to focus on problems or hazards rather than the solutions. As a result, harmful stress occurs. Person's energy is misdirected and starts to finish and mental thoughts deteriorate.

Stress sometimes might give excitement, stimulate the person and can provide new perspectives and new opportunities. This is positive stress and it helps the individual to find new solutions to the problems (Baltaş, 2010). We can use our mind not only to react to stress but we can also use it cope with the stress (Plotnik, 2009).

It is possible to list down the components of the stress as personal expectations and preferrences, pressure and demands brought by changes, and person's ability to cope with stress and his/her perception of that ability. Since the life is never free of stress, we have to learn to keep stress under control; that is, we have to learn to balance among the components of stress (Batlaş, 2010).

Religion is an area that people are very sensitive and interested (Certel, 2008). Religion may play an important role in coping with stress. Different responses are developed for different stress types in various fields in life and, thus, different approaches are adopted to cope with stress. As religion affects and directs people's other attitudes and behaviors, and as it makes the life meaningful, it is obvious that religion has also an important role in coping with stress.

Religious belief provides endurance and resistance to people while they are coping with stressed and stressful situations. This situation relieves the individual and creates a possibility to take the situation more reasonably. In fact, this positive impact of the religion was also seen among the victims of earthquake in 1999 (Kula, 2006).

Religious individuals are more resistant to everyday life troubles. There is a spiritual shelter for religious individuals to refuge when they come across with difficulties. Religious person thinks that life is full of trials and he/she needs to be patient to them (Bilgin, 1997).

In his study, Yapıc1 (2007) found that religion decreases the possibility of committing suicide by giving people hope and trust and that it reduces the negative effects of intense stress and depression. In the research conducted on 200 disabled people by Kula (2005), it has been determined that religion has an important role in coping with the problems and disabled people use religion as a method of coping with stress.

If a person experiences religion honestly and genuinely, it adds the feeling of meaningfulness to his/her life. Person can deal with the challenges of life with this feeling. Religion plays an active role in different ways in coping with stress. If a person is waiting a solution to a problem from the God, it means that he has already chosen a passive stress coping strategy. If the religion is in a position that motivates the individual for a better life, it means that active stress coping method has been chosen. When a person heads God to seek for God's love and compassion, it means that personal security based coping strategy is preferred; interpersonal support based stress coping strategy is selected, when s/he searches for the support of religious association and people; if s/he is at the position of helping others, s/he has problem-solution based stress coping strategy and if a person heads God in order to provide a sensitive security, then it means the sense based coping strategy is chosen.

Patience is based on the belief that unwanted state is temporary and future will be better. Having such a belief results in the feeling of confidence and this confidence feeling prevents person from panic and stress (Öner, 2008).

Dr. Link remarks that he determined that $47 \%$ of the patients in the hospitals that he visited are suffering from nervous disorders. An American physician states that the only way of releasing from these increasingly spreading individual and social disorders lies in "returning to religion" (Pazarl1, 1987).

In the studies conducted in the field, it was found that as the religious level rises, depressive symptoms abates accordingly and that those with high religious level had less depressions and they get better quickly and they have less anxiety and they are in better psychological position than those with low religion level. In addition, it is also remarked that people with higher religious level find life more meaningful and purposeful, and their attempt to suicide is much less and therefore religion is an important factor while coping with stress. According to the studies in the literature review, religiousness has an anxiety-lowering role and there are positive meaningful relations between religious belief and person's feeling better and away from stress. The overall review of most of the studies conducted in the West suggest that religious coping methods are significantly effective in the treatment of stress, negative psychological experiences such as anxiety and depression (Kasapoğlu, 2010). 
Koenig (1998) defines religious as the use of religious beliefs or behaviours that ease solving problems to diminish or prevent the negative emotional consequences of stressful living conditions. Pargament (1997) claims that there are two ways of religious coping; negative religious coping, positive religious coping (cited in Cirhinlioğlu, 2010).

Individuals that tend to have positive religious coping forms believe that there is a good reason of God's actions and there is a meaningful side of the pain and misery that befell on them. Although this kind of belief might indicate a positive effect on one's health and well being, some religious coping forms and thoughts may be harmful to health. Individuals that tend to have negative religious coping forms are most likely think that God has abandoned them or they might think the troubles and sufferings that befell on them is a kind of punishment for their sinful behaviours. Therefore, individuals who use negative religious coping forms may get angry with God and they question why they have been selected to experience those troubles (Cirhinlioğlu, 2010). And this might be a new source of stress for the individual. That is, it is possible to conclude that the reason of an inverse relationship between religiosity and anxiety depends upon using the positive religious coping strategies for stressful situations (Yapıc1, 2007). In this respect, it can also be concluded that the individuals with positive religious coping attitudes have higher possibility of developing and using positive religious coping strategies.

Çayır and Emhan (2010) found that religious values not only have stress reducing, anxiety relieving, and mental health protecting functions but they also have an important role in making life meaningful. According to research findings, owned religious beliefs and values have a significant impact on the interpretation of events in life. There is a significant difference between religious people and nonreligious ones in terms of falling into doubt about God's power and might when they come across stressful events or crisis. So there is a significant difference between individuals that put more emphasis on religious values and those who put less emphasis on religion.

\subsection{Religious Stress}

Piety is not an easy process to live. A person, who has to fulfil some requirements (worships, avoid from forbidden place, etc.) for preferring to be religious and despite this, heaven is still not guaranteed, may also get stressed. He is always somewhere between the fear and hope. He may have stress when he encounters something that religion prohibits, namely, sins. If this condition continues for a long time, religious person faces with greater problems or he applies some different stress-coping strategies to overcome the stress. Hallahmi and Argyle (1997) state that religious people mostly experience the sense of depravity and that there are conflicts between the perception of self and the ideal self (Şahin, 2006).

Güvenç (1991) determined in his study that among the fears, which make young people anxious and disquiet, there are also fears and anxieties about the religion and morals; these fears are resulted from lack of religious knowledge and/or wrong religious education they received. Having any kind of spiritual belief might make individuals happier but this does not necessarily suggest that each religion means worship. There are also some researchers claiming that religious beliefs might also be a source of stress in that some religious teachings might be sources of fear and desperateness and thus it may not cause happiness. Sometimes it is inevitable that individuals, who are religious but do not fulfil the obligations and the requirements of the religion, feel uncomfortable when they are reminded or remembered those obligations. These individuals are those who couldn't develop from the level of believing into the level of real faith (Öner, 2008).

The reason why people are defeated by stress is because of weakened religious beliefs and lacked moral support rather than the impact of technological and cultural conditions. Individual can acquire the necessary moral support by believing in God, serving only to him and by understanding the meaning of actual goal of life and living accordingly. A believer sees his gains and losses as a matter of instrument and never put them into his heart. People, whose realm of heart is not occupied by worldly pleasures, do not have any kind of problem of stress (Peker, 1993).

In his presentation at the international neuropsychiatry congress (May 7, 1970), depending upon his several observations and medical notions, Dr. Özcan from Bakırkoy Mental Hospital, stated that mental disorders is not seen among believers who lives in the direction of religion and who can continue their path steadily. He also adds that mental disorders and any kind of spiritual related neurotic complaints, psychosomatic and behavioral disorders occur only when the individual is moves away from religious direction (Özcan, 1985).

Şahin (2006) remarks in his study that when the density of religion related stress increases, individuals be- 
come more motivated in the direction of piety. In other words, it can be concluded that religion related stress has some positive effects like motivating the individuals in the direction of piety. It can also be said that religious beliefs are one of the most important stress coping methods that can be used in order to meet the needs of individuals, who have stress as a result of inhibitions, obligations, problems and several other reasons.

\section{Method}

\subsection{Purpose and Importance of Research}

In this study it was investigated that whether there is a meaningful difference among the participants' stress coping attitudes according to their gender, age, education level, economic income, religious knowledge, perceived level of piety, and their religious level and religious education they received.

This current study is also important because this is the first study that has ever been done in the field of stress coping strategies considering the religious developmental stages of those over the age of fifteen.

\subsection{Method of the Study}

The research is a descriptive study designed to determine the effects of religious attitudes to cope with stress. Therefore, the theoretical part of the study was carried out by using documentation methods and techniques, while the model of practical research of the study was carried out by using survey model (Karasar, 2010) and questionnaires in order to describe a condition that there used to be in the past or that still exists.

\subsection{Workgroup-Population and Sample}

The population of the study is consisted of individuals living in Denizli city center, at the age of 15 and over. The study sample is constituted by 869 randomly selected individuals from 381.000 people

\subsection{Data Collection Tools}

In this study, in order to measure the stress coping attitudes, "Stress Coping Attitude Inventory" which was adapted to Turkish by Özbay and Şahin (1997) was used. Original form of the inventory is "stress coping attitudes scale" which was developed by Özbay (1993) for foreign subjects studying at universities in USA. The Turkish version of the Inventory was designed by Özbay and Şahin (1997). The purpose of this inventory is investigate the individuals' stress coping attitudes in various stressful situations.

At the process of adapting to Turkish, as a result of factor analysis, 43 expressions from 56 items of the original coping inventory were grouped into six factors. Inventory was developed by using with 5-point Likert-type scale and participants were asked to read all the items and mark one of the options: "never", "occasionally", "sometimes", "often", "always". Subjects were also asked to choose and mark the most appropriate choice for themselves for each item.

Six factors that were identified by factor analysis technique are: active planning, search for external aid, seek refuge in religion, escape-abstraction (emotional-operative) escape isolation (biochemical) and acceptance-cognitive restructuring. In addition to the structure factor analysis, with the help of similar scales, some findings about the validity of the test were able to be obtained. Stress Coping Methods Scale (SCMS), which was adapted to Turkish by Şahin and Durak (1995), was considered as the basic measurement tool. It was found that correlation level between SCMS and SCAI was found to be $0.54(p<0.001)$ in general. Reliability calculations of the test were performed by using Cronbach's alpha internal consistency method. Overall reliability coefficiency of the test was found 0.81 . Considering the time period since the scale was developed, reapplication was conducted for this study and the overall reliability coefficiency of the test was found to be 0.82 .

\subsection{Analysis of Data and Used Statistical Techniques}

"Stress Coping Attitude Inventory" data are analysed through "Analysis of variance (Anova-Tukey)", "T-Test" by using software program "SPSS 17.0 for windows". Analysis of variance (Anova) shows whether various different groups are different from each other or not in terms of score meanings.

Tukey-test is necessary as well as variance analysis in order to gather necessary information about the differences among groups. Tukey compares each group one another in pairs and shows which groups have differences. 
At times, although there are differences between groups, significant difference might occur between the groups. T-test is used to test the hypothesis whether the means of two samples are equal or not (Tonta, 2012).

Generally accepted significance level in academic studies (maximum margin of error) is 0.05 . If the result of the analysis is higher level of materiality, they are indicated as $p<0.01$ or $p<0.001$. If it is $p<0.05$ in the Anova, mean averages of groups are not equal and there is a significant difference between them. If it is $p>0.05$, the mean averages of groups are statistically equal and the difference between the groups is not significant.

The responses that the participants provided for each item ranges from 0.00 to 4.00 in 5-point Likert-type scales. Intervals in the scale are designed by equally spaced 5 coloums and 4 rows and in order to determine the values of the rows in the scale $\mathrm{K}-1 / \mathrm{K}(5-1=44 / 5=0.80)$ equation was used. The limit values of rows according to this equation are given in Table 1.

\subsection{General Demographic Information about the Participants}

The table below shows some information about the participants of the study, particularly those whose surveys were found to be valid (Table 2).

When the gender variance of the subjects is considered, it is seen that $49 \%$ of the participants is male and $51 \%$ is female.

When the age range of the subjects, which were determined according to the time period of religious development, is considered, those at the age between 22 - 40 were ranked first by $35.3 \%$ in the answers provided. They are followed by other age groups 41 - 60 by 25.7\%, 18 - 21 by $17.5 \%, 61$ and above by $8.5 \%$ and $15-17$ age group by $13 \%$ respectively. Considering the age of participants, it is seen that $65.8 \%$ of them are under 41 years old (Table 3 ).

When the subjects' educational status is considered, it is seen that $27 \%$ of the participants have associate degree and bachelor's degree, $25.5 \%$ of them are high school graduates, $22.8 \%$ secondary school, $19.7 \%$ elementary school, $2.8 \%$ postgraduate and $2.2 \%$ of them are those who never took school education (Table 4).

When we look at perceptions of income level of the respondents, it is seen that $57.3 \%$ of them are of the opinion that they have average income, $30 \%$ of them think that they have high income, $9.3 \%$ of the participants think that they have low level income, and $2 \%$ of the respondents think that they have very low level income, and only $1.4 \%$ of the respondents think that they have very high level income (Table 5).

Considering the distribution of the subjects according to their religious knowledge, it is seen that $50.2 \%$ of them think that their religious knowledge is at good level, while $37.5 \%$ of them thinks that their religious knowledge is at medium level, $7.2 \%$ thinks that their religious knowledge is low-insufficient and $5.1 \%$ thinks that their religious knowledge is very good (Table 6).

Table 1. Range value limits about agreement on the items of stress coping attitude inventory (SCAI).

\begin{tabular}{cccc}
\hline Level & $\begin{array}{c}\text { SCAI Level of } \\
\text { Agreement }\end{array}$ & Point & Point limit \\
\hline Very high & Always & 4 & $3.21-4.00$ \\
High & Often & 3 & $2.41-3.20$ \\
Medium & Sometimes & 2 & $1.61-2.40$ \\
Low & Seldom & 1 & $0.81-1.60$ \\
Very low & Never & 0 & $0.00-0.80$ \\
\hline
\end{tabular}

Table 2. Gender distribution of the participants.

\begin{tabular}{ccc}
\hline & Number & $\%$ \\
\hline Female & 443 & 51 \\
Male & 426 & 49 \\
Total & 869 & 100 \\
\hline
\end{tabular}


Table 3. Age distribution of the participants.

\begin{tabular}{ccc}
\hline & Number & $\%$ \\
\hline $15-17$ & 113 & 13.0 \\
$18-21$ & 152 & 17.5 \\
$22-40$ & 307 & 35.3 \\
$41-60$ & 223 & 25.7 \\
61 and over & 74 & 8.5 \\
Total & 869 & 100 \\
\hline
\end{tabular}

Table 4. Distribution of the participants according to their education level.

\begin{tabular}{ccc}
\hline & Number & $\%$ \\
\hline Never Attended Any School & 19 & 2.2 \\
Primary School & 171 & 19.7 \\
Secondary School & 198 & 22.8 \\
High School & 222 & 25.5 \\
Bachealor & 235 & 27.0 \\
Post-graduate (Master and Doctorate) & 24 & 2.8 \\
Total & 869 & 100 \\
\hline
\end{tabular}

Table 5. Distribution of income status of the participants.

\begin{tabular}{ccc}
\hline & Number & $\%$ \\
\hline Very low & 17 & 2.0 \\
Low & 81 & 9.3 \\
Medium & 498 & 57.3 \\
Good & 261 & 30.0 \\
Very good & 12 & 1.4 \\
Total & 869 & 100 \\
\hline
\end{tabular}

Table 6. Distribution of the participants according to their religious knowledge level.

\begin{tabular}{ccc}
\hline & Number & $\%$ \\
\hline Poor-Insufficient Insufficient & 63 & 7.2 \\
Good & 326 & 37.5 \\
Very good & 436 & 50.2 \\
Total & 44 & 5.1 \\
\hline
\end{tabular}

Considering the distribution of the responses to the question about their piety perception level, it was found that the majority of them (73.9\%), describe themselves as religious, $19.8 \%$ of them see themselves less religious, $4.4 \%$ thinks that they are devoutly religious, $2 \%$ of them see themselves irrelevant to religion (Table 7).

When analysing the table about where subjects received their religious education, it is seen that the ratio of those who never received religious education is $1.8 \%$. The ratio of those who received religious education in their families is 67\%; and those who received religious education in Quran course is 38.1\%, while the ratio of 
those who received religious education from imam is $43 \%$; those who received religious education from religious culture and ethics course is $39.9 \%$; $51.4 \%$ received religious education from religious books; $17.5 \%$ of them received religious education from Imam Hatip High Schools and those who received religious education from other sources is $9.7 \%$ (Table 8 ).

\subsection{Findings and Analysis}

Findings and comments about whether there is significant difference between subjects' demographics such as gender, age, education, economic income, religious knowledge, perceived level of piety, and where they receive religious education and stress coping attitudes or not are given below.

Table 9 indicates that stress coping attitudes don't differ according to gender. $\mathrm{t}(847)=0.88, p>0.05$.

The mean average of stress coping attitude scale of women participated in the study is $\bar{X}=2.09$, while it is $\bar{X}=2.07$ among men. Even if there isn't statistically a significant difference between the two, it can be seen that women have a higher average of stress coping attitude than men.

Table 10 shows that stress coping attitudes show difference according to the ages $\left(\mathrm{F}_{(4 ; 864)}\right)=4.27, p<0.05$.

Table 7. Distribution of participants perceived religious levels.

\begin{tabular}{ccc}
\hline & Number & $\%$ \\
\hline Irrelevant to Religion & 17 & 2.0 \\
Less Religious & 172 & 19.8 \\
Religious & 642 & 73.9 \\
Very Religious & 38 & 4.4 \\
Total & 869 & 100 \\
\hline
\end{tabular}

Table 8. Distribution of the education sources according to where the participants received their religious education.

\begin{tabular}{|c|c|c|c|c|}
\hline & & Yes & No & Total \\
\hline \multirow{2}{*}{$\begin{array}{c}\text { Never Had a Religious } \\
\text { Education }\end{array}$} & Number & 16 & 853 & 869 \\
\hline & Percentage & 1.8 & 98.2 & 100 \\
\hline \multirow{2}{*}{ Family } & Number & 582 & 287 & 869 \\
\hline & Percentage & 67.0 & 33.0 & 100 \\
\hline \multirow{2}{*}{ Quran Course } & Number & 331 & 538 & 869 \\
\hline & Percentage & 38.1 & 61.9 & 100 \\
\hline \multirow{2}{*}{ Imam } & Number & 374 & 495 & 869 \\
\hline & Percentage & 43.0 & 57.0 & 100 \\
\hline \multirow{2}{*}{$\begin{array}{l}\text { Religious Culture and } \\
\text { Ethics Course }\end{array}$} & Number & 347 & 522 & 869 \\
\hline & Percentage & 39.9 & 60.1 & 100 \\
\hline \multirow{2}{*}{ From Religious Books } & Number & 447 & 422 & 869 \\
\hline & Percentage & 51.4 & 48.6 & 100 \\
\hline \multirow{2}{*}{ Imam Hatip High School } & Number & 152 & 717 & 869 \\
\hline & Percentage & 17.5 & 82.5 & 100 \\
\hline \multirow{2}{*}{ Other } & Number & 84 & 785 & 869 \\
\hline & Percentage & 9.7 & 90.3 & 100 \\
\hline
\end{tabular}


Table 9. T-test results of SCA means according to the genders of the participants.

\begin{tabular}{ccccccccc}
\hline & Gender & $\mathrm{N}$ & $\bar{X}$ & $\mathrm{~S}$ & $\mathrm{SD}$ & $\mathrm{t}$ & $\mathrm{Sd}$ & $p$ \\
\hline \multirow{2}{*}{ SCA (Overall) } & Female & 443 & 2.09 & 0.37 & 0.02 & & & \\
& Male & 426 & 2.07 & 0.41 & 0.02 & 0.880 & 847.59 & 0.379 \\
\hline
\end{tabular}

Table 10. Variance analysis of SCA results (Anova-Tukey) according to the ages of the participants.

\begin{tabular}{|c|c|c|c|c|c|c|c|}
\hline & $\begin{array}{c}\text { Resource of the } \\
\text { Variance }\end{array}$ & $\begin{array}{l}\text { Sum of } \\
\text { Squares }\end{array}$ & sd & Saquare Mean & $\mathrm{F}$ & $p$ & $\begin{array}{c}\text { Meaningful } \\
\text { Difference } \\
\text { Among Groups }\end{array}$ \\
\hline \multirow{3}{*}{ SCA (Overall) } & Intergroup & 2.57 & 4.00 & 0.64 & 4.27 & 0.002 & \multirow{3}{*}{$\begin{array}{l}1-5^{*} \\
2-5^{*} \\
3-5^{*}\end{array}$} \\
\hline & In-group & 129.84 & 864.00 & 0.15 & & & \\
\hline & Total & 132.41 & 868.00 & & & & \\
\hline
\end{tabular}

*1. 15 - 17, 2. 18 - 21, 3.22 - 40, 4. 41 - 60, 5. 61 and over.

The highest stress coping attitudes average according to age groups seems to belong to the age group of 61 over. Group at the age of 41 to 60 has the average $(\bar{X}=2.12)$, the group at the ages of 22 to 40 has $(\bar{X}=2.06)$, the group consisted of the ages 18 to 21 has the average $(\bar{X}=2.04)$ and participants at the ages of 15 to 17 has the lowest average ( $\bar{X}=2.01$ ). The groups that have significant meaningful differences are those at the age of 1 to 5,2 to 5 and 3 to 5 (Table 11 ).

It was found that the lowest average of stress coping attitude according to age groups belongs to the age group of 15 to 17 . The last period of adolescence starts at the ages around 15 - 17 and goes on until the end of 21, the onset of the adulthood. The physical and mental developments continue during this period (Peker, 2008). This turbulent period of the teenager also affects its ability to cope with stress. The subjects at the age of 61 and over have the highest average. In terms of developmental characteristics, this age group is considered to have completed their physical and mental development. It is seen that this age group has more life experience than other age groups. This age group is more conscious and determined and more resistant to stressful factors in their actions. Considering the overall results of the data, it can safely be concluded that stress coping skills increases in accordance with their developmental period.

When the data in Table 12 is analysed, it is seen that stress coping attitudes vary according to the education level. $\left(\mathrm{F}_{(5 ; 863)}\right)=4.50, p<0.01$

As can be seen in Table 13, the highest average ( $\bar{X}=2.33$ ) in stress coping attitude according to education level seems to belong to the group who never received school education. Group of those who received primary school education ( 1 - 5 years) was found to have an average $(\bar{X}=2.15)$; those who had postgraduate degree have average by $\bar{X}=2.10$; the group that was consisted of the graduates of high school have an average ( $\bar{X}=$ 2.09); the mean value of those who are the graduates of associate degree - bachelor's degree is $(\bar{X}=2.05)$, and those who are graduates of secondary-primary school were found to have the lowest average $(\bar{X}=2.01)$. Groups that have significant differences between each other are the groups are those with the education level of $1-3,1-5$, and $2-3$.

As the highest average of stress coping attitude averages according to education level belongs to those who never took school education, considering the compulsory primary school education in our country, it can be concluded that those who stated that they never took school education might be at older ages and they might have completed their personality development. The reason of this high average of this group's stress coping attitude should not be related to education level, but the age factor.

Table 14 reveals that stress coping attitudes don't change according to people's income status. $\left(\mathrm{F}_{(4 ; 864)}\right)=0.97$, $p>0.05$.

In Table 15, it is seen that there is no significant meaningful relationship between income status and stress coping attitudes and the highest average of stress coping attitudes $(\bar{X}=2.18)$ belongs to the group of those who has very high-level income. Group of those with very low income has average ( $\bar{X}=2.15$ ); and those with low level income has an average ( $\bar{X}=2.13)$; those with high level income has an average $(\bar{X}=2.08)$, and the group with middle income has the lowest average level $(\bar{X}=2.06)$. 
Table 11. Distribution of SCA means according to the ages of the participants.

\begin{tabular}{ccccccccc}
\hline & Age & $\mathrm{N}$ & $\bar{X}$ & $\mathrm{~S}$ & St. Deviation & The lowest & The Highest \\
\hline & $15-17$ & 113 & 2.01 & 0.33 & 0.03 & 1.19 & 2.60 \\
SCA (Overall) & $18-21$ & 152 & 2.04 & 0.37 & 0.03 & 1.14 & 3.70 \\
& $22-40$ & 307 & 2.06 & 0.39 & 0.02 & 1.02 & 3.35 \\
& $41-60$ & 223 & 2.12 & 0.39 & 0.03 & 1.12 & 3.21 & 3.53 \\
& 61 and over & 74 & 2.21 & 0.49 & 0.06 & 1.02 & 3.70 \\
\hline
\end{tabular}

Table 12. Variance analysis of SCA results (Anova-Tukey) based on the participants' educational status.

\begin{tabular}{ccccccc}
\hline & $\begin{array}{c}\text { Source of } \\
\text { Variance }\end{array}$ & $\begin{array}{c}\text { Sum of } \\
\text { Squares }\end{array}$ & sd & Mean Square & F & $\begin{array}{c}\text { Integroup } \\
\text { Difference }\end{array}$ \\
& Intergroup & 3.36 & 5.00 & 0.67 & 4.50 & 0.000 \\
SCA (Overall) & In-Group & 129.05 & 863.00 & 0.15 & $1-3^{*}$ \\
& Total & 132.41 & 868.00 & & $1-5^{*}$ \\
& & & &
\end{tabular}

*1. Never attended school, 2. Primary School 1 - 5, 3. Ortaokul-ilköğretim, 4. Secondary-High School, 5. associate-university, 6. Postgraduate.

Table 13. Distribution of SCA means according to the participants' educational background.

\begin{tabular}{ccccccccc}
\hline Education Status & $\mathrm{N}$ & $\bar{X}$ & $\mathrm{~S}$ & St. Deviation & The Lowest & The Highest \\
\hline & Never Attended Any Schools & 19 & 2.33 & 0.37 & 0.08 & 1.88 & 2.95 \\
Primary School 1 - 5 & 171 & 2.15 & 0.44 & 0.03 & 1.02 & 3.53 \\
& Secondary-Primary Education & 198 & 2.01 & 0.36 & 0.03 & 1.07 & 2.81 \\
SCA (Overall) & secondary Education (High School) & 222 & 2.09 & 0.41 & 0.03 & 1.02 & 3.70 \\
& Associate-Degree/Bachelor's Degree & 235 & 2.05 & 0.35 & 0.02 & 1.05 & 3.14 \\
& Post Graduate & 24 & 2.10 & 0.35 & 0.07 & 1.49 & 2.77 \\
Total & 869 & 2.08 & 0.39 & 0.01 & 1.02 & 3.70 \\
\hline
\end{tabular}

Table 14. Variance analysis (Anova-Tukey) results of SCA means of the participants according to their in-come status.

\begin{tabular}{|c|c|c|c|c|c|c|c|}
\hline & $\begin{array}{l}\text { Resource of } \\
\text { Variance }\end{array}$ & Sum of Squares & sd & Mean Squares & $\mathrm{F}$ & $p$ & $\begin{array}{l}\text { Intergroup } \\
\text { Meaningful } \\
\text { Difference }\end{array}$ \\
\hline \multirow{3}{*}{ SCA (Overall) } & Intergroup & 0.59 & 4.00 & 0.15 & 0.97 & 0.425 & \\
\hline & In-Group & 131.82 & 864.00 & 0.15 & & & - \\
\hline & Total & 132.41 & 868.00 & & & & \\
\hline
\end{tabular}

Table 15. Distribution of SCA means according to the income status of the participants.

\begin{tabular}{|c|c|c|c|c|c|c|c|}
\hline & Income Status & $\mathrm{N}$ & $\bar{X}$ & $\mathrm{~S}$ & St. Mistake & The Lowest & The Highest \\
\hline \multirow{6}{*}{ SCA (Overall) } & Very Low & 17 & 2.15 & 0.36 & 0.09 & 1.51 & 2.67 \\
\hline & Low & 81 & 2.13 & 0.46 & 0.05 & 1.42 & 3.70 \\
\hline & Of Medium & 498 & 2.06 & 0.40 & 0.02 & 1.02 & 3.53 \\
\hline & Good & 261 & 2.08 & 0.36 & 0.02 & 1.05 & 3.05 \\
\hline & Very Good & 12 & 2.18 & 0.33 & 0.09 & 1.53 & 2.63 \\
\hline & Total & 869 & 2.08 & 0.39 & 0.01 & 1.02 & 3.70 \\
\hline
\end{tabular}


According to findings of the research, though it was found that stress coping attitudes do not change according to the income status, it can be concluded that the group of very high-level income, with sufficient financial resources, has a higher attitude than other groups. It can also be suggested that the reason why the group with middle income has the lowest average attitude might be because individuals who can meet their financial needs may want to reach economically upper status and they may even have ambition for it and this situation might have been effecting the stress coping attitudes negatively.

Table 16 shows that stress coping attitudes show varience according to religious knowledge of the respondents. $\left(\mathrm{F}_{(3 ; 865)}\right)=5.05, p<0.05$.

It is seen that the highest average ( $\bar{X}=2.22$ ) in stress coping attitudes according to the religious knowledge belongs to the group of those whose religious knowledge is very well. The group, whose religious knowledge is at good level has an average ( $\bar{X}=2.10$ ); the group, whose religious knowledge is at middle level has an average $(\bar{X}=2.05)$; the group with low-insufficient religious knowledge has an average $(\bar{X}=1.96)$. Groups that have significant differences between each others are the groups that are at the religious knowledge level of 1 - 3, 1 - 5, and 2 - 4 (Table 17).

It is remarkable that the highest average in the stress coping attitudes belongs to the group of those whose religious knowledge is very well, and the lowest average belongs to the group with low-insufficient religious knowledge.

Considering the data in Table 18, it is seen that stress coping attitudes vary according to the perceived religiousness level of the participants. $\left(\mathrm{F}_{(3 ; 865)}\right)=14.86, p<0.01$.

It is seen in Table 19 that the highest average $(\bar{X}=2.25)$ in stress coping attitudes according to the perceived religiousness level belongs to the group of those who are devoutly religious. The group of those who defined themselves religious has average attitude level $(\bar{X}=2.11)$; the group of those who are irrelevant to religious has average ( $\bar{X}=1.93)$; and the group of those who are less religious has the lowest average $(\bar{X}=1.92)$. Groups that have significant differences between each other are the groups that are at the $1-4,2-3$, and 2 - 4 perceived religiousness level.

It was found that the highest average of stress coping attitudes belongs to the group of those who are devoutly religious and religious, and the groups of those who are irrelevant to religion and less religious ones has the lowest attitude level shows that religiousness is one of the most effective ways in coping with stress.

Table 16. Variance analysis (Anova-Tukey) results of SCA means of the participants according to their religious knowledge levels.

\begin{tabular}{cccccccc}
\hline & $\begin{array}{c}\text { Resource of } \\
\text { Variance }\end{array}$ & $\begin{array}{c}\text { Sum of } \\
\text { Squares }\end{array}$ & sd & Mean Squares & F & $p$ & $\begin{array}{c}\text { Intergroup } \\
\text { Meaningful } \\
\text { Difference }\end{array}$ \\
\hline \multirow{5}{*}{ SCA (Overall) } & Intergroups & 2.28 & 3.00 & 0.76 & 5.05 & 0.002 & $1-3^{*}$ \\
& In-groups & 130.13 & 865.00 & 0.15 & & $1-4^{*}$ \\
& Total & 132.41 & 868.00 & & & $2-4^{*}$ \\
\end{tabular}

*1. Poor-insufficient, 2. Medium, 3. Good, 4. Very good.

Table 17. Distribution of SCA means according to religious knowledge level of the participants.

\begin{tabular}{|c|c|c|c|c|c|c|c|}
\hline & $\begin{array}{c}\text { Religious } \\
\text { Knowledge } \\
\text { Level }\end{array}$ & $\mathrm{N}$ & $\bar{X}$ & $\mathrm{~S}$ & SD & The Lowest & The Highest \\
\hline \multirow{5}{*}{ SCA (Overall) } & Poor-Insufficient & 63 & 1.96 & 0.46 & 0.06 & 1.02 & 3.53 \\
\hline & Medium & 326 & 2.05 & 0.38 & 0.02 & 1.07 & 3.35 \\
\hline & Good & 436 & 2.10 & 0.38 & 0.02 & 1.02 & 3.70 \\
\hline & Very Good & 44 & 2.22 & 0.37 & 0.06 & 1.53 & 3.09 \\
\hline & Total & 869 & 2.08 & 0.39 & 0.01 & 1.02 & 3.70 \\
\hline
\end{tabular}


Table 18. Variance analysis (Anova-Tukey) results of SCA means of the participants according to their level of perceived religiousness.

\begin{tabular}{cccccccc}
\hline & $\begin{array}{c}\text { Variance } \\
\text { Resource }\end{array}$ & $\begin{array}{c}\text { Sum of } \\
\text { Squares }\end{array}$ & sd & Mean Squares & F & $p$ & $\begin{array}{c}\text { Intergroup } \\
\text { Meaningful } \\
\text { Difference }\end{array}$ \\
\hline & Inter-Group & 6.49 & 3.00 & 2.16 & 14.86 & 0.000 & $1-4^{*}$ \\
SCA(Overall) & In-Group & 125.92 & 865.00 & 0.15 & & $2-3^{*}$ \\
& Total & 132.41 & 868.00 & & & $2-4^{*}$ \\
& & & & & & & \\
\hline
\end{tabular}

*1. Irrelevant to religion, 2. Less religious, 3. Religious, 4. Very religious.

Table 19. Distribution of SCA means according to perceived religiousness levels of the participants.

\begin{tabular}{|cccccccc}
\hline & $\begin{array}{c}\text { Perceived } \\
\text { Religiousness } \\
\text { Level }\end{array}$ & $\mathrm{N}$ & $\bar{X}$ & $\mathrm{~S}$ & $\mathrm{SD}$ & The Lowest & The Highest \\
\hline \multirow{3}{*}{ SCA (Overall) } & Irrelevant to Religion & 17 & 1.93 & 0.53 & 0.13 & 1.02 & 3.53 \\
& Less Religious & 172 & 1.92 & 0.38 & 0.03 & 1.05 & 3.35 \\
& Religious & 642 & 2.11 & 0.38 & 0.01 & 1.02 & 3.70 \\
& Very Religious & 38 & 2.25 & 0.33 & 0.05 & 1.42 & 3.09 \\
& Total & 869 & 2.08 & 0.39 & 0.01 & 1.02 & 3.70 \\
\hline
\end{tabular}

Topuz (2003) in his study states that while the people taking place in the dimension of positive direction of religious developmental process are more eager to attempt to solve the problem, to seek for support from their environment, take the situation from a positive perspective and they can express themselves easily, the people experiencing negative religious developmental process often avoid expressing their feelings and ignore the situation or they try to forget it and they often use drug or alcohol to do so. This is compatible with the findings of our study.

Table 20 shows that stress coping attitudes vary according to religious education that the participants received in the family. $\mathrm{t}(867)=2.201, p<0.05$.

The average stress coping attitude level of the participants who received religious education in their families was found to be $\bar{X}=2.11$ and of those who do not get it in their families is $\bar{X}=2.05$. There is a statistically meaningful difference between the two groups. Those who get religious education in their families have a higher average in stress coping attitudes compared to those who do not get religious education in their families.

It can be concluded that having religious education in family is more beneficial and useful in coping with stress than not receiving it in at home. It should also be considered that another factor or factors other than getting religious education in family can be effective in the stress that the people have. For example, it can be thought that some behaviours as parents' democratic attitudes or whether they are having religious life that they tell and want to have or not might have either positive or negative contribution to the individuals' stress. Şahin (2006) stated in his study that parents' religiousness as well as their personality can have influence on their children's religion-related stress and its frequency; if parents are oppressive and rigid religious, this oppression can result in stress that children have. Şahin (2006) suggests in his study that the lowest frequency level of religionrelated stress belongs to the individuals who see the religiosity level of their families high and those who see the religiosity level of their families as oppositely low. This partially supports our findings of the research.

When Table 21 is analysed, it is seen that stress coping attitudes do not vary according to the religious education received in a Quran course: $\mathrm{t}(867)=0.817, p>0.05$.

The average stress coping level of the respondents, who get religious education in Quran course was found $\bar{X}=2.08$ and of those who did not receive it in a Quran course was found $\bar{X}=2.06$. Although there is not statistically meaningful difference between the two groups, it can be concluded that the respondents who had their religious education at a Quran course have a higher average in stress coping attitudes compared to those who did not receive religious education in Quran course. 
These results suggest that religious instructions in Quran courses are not effective in coping with the stress; providing educational personal and course curriculum should be reinforced about some topics such as "religious coping" and "stress coping".

Table 22 indicates that stress coping attitudes do not vary according to religious education that received from Imam. $\mathrm{t}(867)=0.727, p>0.05$.

The average stress coping level of the respondents who received religious education from Imam, was found $\bar{X}=2.09$ nd of those who do not get it from Imam was found $\bar{X}=2.07$. Although there is not statistically meaningful difference between the two groups, it can be stated that the respondents who received religious education from Imam, have a higher average in stress coping attitudes compared to those, who did no get religious education from Imam.

According to the results of the study, there is no significant difference between those who get religious education from Imam and those who do not get it from Imam in terms of dealing with stressful situations. To sum up, it can be concluded that Imams have very little positive effect on the community's stress coping ability.

Table 23 shows that stress coping attitudes do not vary according to religious education received in the course of Religion and Ethics at school. $\mathrm{t}(867)=0.7, p>0.05$.

The average stress coping level of the respondents who had religious education in the course of Religion and Ethics at school is $\bar{X}=2.09$ and those who do not get it at school is $\bar{X}=2.07$. Although there is not statistically meaningful difference between the two groups, it is seen that those who get religious education at Religion and Ethics course have a higher average in stress coping attitudes compared to those who did not get it at the course of Religion and Ethics.

Table 20. T-Test results of SCA means according to whether the participants received religious education from their families.

\begin{tabular}{ccccccccc}
\hline & Family & $\mathrm{N}$ & $\bar{X}$ & $\mathrm{~S}$ & $\mathrm{SD}$ & $\mathrm{t}$ & $\mathrm{Sd}$ & $p$ \\
\hline \multirow{3}{*}{ SCA (Overall) } & Yes & 331 & 2.11 & 0.36 & 0.02 & & & \\
& No & 538 & 2.05 & 0.41 & 0.02 & 2.201 & 867 & 0.028 \\
\hline
\end{tabular}

Table 21. T-Test results of SCA means according to whether the participants received their religious education at a Quran course.

\begin{tabular}{ccccccccc}
\hline & Quran Course & $\mathrm{N}$ & $\bar{X}$ & $\mathrm{~S}$ & $\mathrm{SD}$ & $\mathrm{t}$ & $\mathrm{Sd}$ & $p$ \\
\hline \multirow{2}{*}{ SCA (Overall) } & Yes & 582 & 2.08 & 0.39 & 0.02 & & & \\
& No & 287 & 2.06 & 0.40 & 0.02 & 0.817 & 867 & 0.414 \\
\hline
\end{tabular}

Table 22. T-Test results of SCA means according to whether they received their religious education from Imam.

\begin{tabular}{|c|c|c|c|c|c|c|c|c|}
\hline & Imam & $\mathrm{N}$ & $\bar{X}$ & S & $\mathrm{SD}$ & $\mathrm{t}$ & Sd & $p$ \\
\hline \multirow{3}{*}{ SCA (Overall) } & Yes & 374 & 2.09 & 0.39 & 0.02 & \multirow{3}{*}{0.727} & \multirow{3}{*}{867} & \multirow{3}{*}{0.468} \\
\hline & & & & & & & & \\
\hline & No & 495 & 2.07 & 0.39 & 0.02 & & & \\
\hline
\end{tabular}

Table 23. T-Test results of SCA means according to whether they received their religious education at the course of religious culture and ethics.

\begin{tabular}{ccccccccc}
\hline & $\begin{array}{c}\text { Religious } \\
\text { Culture and } \\
\text { Ethics Couse }\end{array}$ & $\mathrm{N}$ & $\bar{X}$ & $\mathrm{~S}$ & $\mathrm{SD}$ & $\mathrm{t}$ & $\mathrm{Sd}$ & \\
\hline SCA (Overall) & Yes & 347 & 2.09 & 0.38 & 0.02 & 0.700 & 867 \\
& No & 522 & 2.07 & 0.40 & 0.02 & & \\
\hline
\end{tabular}


The results suggest that Religion and Ethics course has very little contribution to stress coping attitudes and that the course should be reinforced about some topics such as "religious coping", "stress-coping".

In Table 24, it is seen that stress coping attitudes vary according to religious education received from religious books. $\mathrm{t}(867)=4.981, p<0.01$.

The average stress coping level of the respondents who got their religious education from religious books is $\bar{X}=2.14$ and those who did not get it from religious books is $\bar{X}=2.01$. There is a statistically meaningful difference between the two groups. It suggests that people who had religious education from religious books have a higher average stress coping attitudes when compared to those who did not get it from religious books.

It can be concluded that getting religious education from religious books contributes to stress coping and religious publications have an important influence on the individuals in stress coping.

In Table 25, it can be seen that stress coping attitudes do not vary according to getting religious education at Imam Hatip High School. t(867) $=1.712, p>0.05$.

The average stress coping level of the respondents who had a religious education from Imam Hatip High School is $\bar{X}=2.13$ and of those who did not get it from Imam Hatip High School is $\bar{X}=2.07$. Although there is not statistically meaningful difference between the two groups, it is seen that the subjects, who has a religious education at Imam Hatip High School have a higher average in stress coping attitudes compared to those who did not get it at Imam Hatip High School.

It can be concluded that the reason why there is little or no significant difference between the two groups might suggest that the education of those schools might not help students gain enough problem-solving and coping with challenges skills to students.

Table 26 shows that stress coping attitudes do not vary according to getting religious education from other sources. $\mathrm{t}(867)=-0.333, p>0.05$.

The average stress coping level of the respondents who had religious education from other sources, is $\bar{X}=$ 2.06 and of those who did not get it from other sources is $\bar{X}=2.08$. Although there is not statistically meaningful difference between the two groups, it can safely be stated that those who received religious education from other sources have a lower average in stress coping attitudes compared to those who did not get it from other sources.

This might suggest that the reason why there is no significant difference between those who get religious education from other sources and those who did not in terms of stress coping attitudes might be because of they are various and there is no one standard.

Table 24. T-Test results of SCA means according to whether they received their religious education from religious books.

\begin{tabular}{ccccccccc} 
& $\begin{array}{c}\text { Religious } \\
\text { Books }\end{array}$ & $\mathrm{N}$ & $\bar{X}$ & $\mathrm{~S}$ & $\mathrm{SD}$ & $\mathrm{t}$ & $\mathrm{Sd}$ & $p$ \\
\hline \multirow{2}{*}{ SCA (Overall) } & Yes & 447 & 2.14 & 0.37 & 0.02 & \multirow{2}{*}{0.981} & 867 & 0.000 \\
& No & 422 & 2.01 & 0.40 & 0.02 & & \\
\hline
\end{tabular}

Table 25. T-Test results of SCA means according to whether they received their religious education at Imam Hatip High Schools.

\begin{tabular}{|c|c|c|c|c|c|c|c|c|}
\hline & $\begin{array}{l}\text { Imam Hatip } \\
\text { High School }\end{array}$ & $\mathrm{N}$ & $\bar{X}$ & $\mathrm{~S}$ & SD & $\mathrm{t}$ & $\mathrm{Sd}$ & $p$ \\
\hline \multirow{2}{*}{ SCA (Overall) } & Yes & 152 & 2.13 & 0.39 & 0.03 & \multirow[b]{2}{*}{1.712} & \multirow[b]{2}{*}{867} & \multirow[b]{2}{*}{0087} \\
\hline & No & 717 & 2.07 & 0.39 & 0.01 & & & \\
\hline
\end{tabular}

Table 26. T-Test results of SCA means according to whether they received their religious education from other sources.

\begin{tabular}{cccccccc}
\hline & $\begin{array}{c}\text { Other } \\
\text { Sources }\end{array}$ & $\mathrm{N}$ & $\bar{X}$ & $\mathrm{~S}$ & $\mathrm{SD}$ & $\mathrm{t}$ & $\mathrm{Sd}$ \\
\hline \multirow{2}{*}{ SCA (Overall) } & Yes & 84 & 2.06 & 0.35 & 0.04 & -0.333 & 867 \\
& No & 785 & 2.08 & 0.39 & 0.01 & 0.740 \\
\hline
\end{tabular}




\section{Conclusions and Suggestions}

\subsection{Conclusions}

The results statistically showed that stress coping attitudes don't differ significantly according to the gender, and although there is statistically no significant difference between these genders, women have higher attitude average than men.

It was found that stress coping attitudes statistically differ significantly according to the age and the group of those at the age of 61 years and over group has the highest average in stress coping attitude, which was followed by the age group of $41-60,22$ - 40 and 18 - 21 respectively and the lowest average belongs to the age group of 15 - 17 years old.

The results also showed that there is a statistically meaningful difference in stress coping attitudes according to the education level and that the group of those who never took school education has the highest average in stress coping attitude averages, which is followed by the group of those graduated from elementary school, postgraduates, graduates of high school, and the group of those who had an associate degree - bachelor's degree and the lowest average attitude was found to belong to the graduates of secondary school.

The results indicated that there is no statistically meaningful difference in stress coping attitudes according to the income levels of the respondents. The group of very high level income has the highest average in stress coping attitude averages according to the income statue, which was followed respectively by the group of very low level income, group of low level income, and group of high level income and the group of middle income was found to have the lowest average stress coping attitudes.

It was also found that stress coping attitudes differ significantly according to the people's religious knowledge. The group of those whose religious knowledge is very well has the highest average in stress coping attitude, which is followed respectively by the group of those whose religious knowledge is at good level, and group of those whose religious knowledge is at middle level and the lowest average attitude level occurs among the members of the group with low-insufficient religious knowledge.

The results showed that stress coping attitudes differ significantly according to the perceived religiousness levels of the respondent. The group of those who are devoutly religious has the highest average in stress coping attitude averages according to the piety level, and is followed respectively by the group of religious, group of irrelevant to religious, and of all, the group of less religious had the lowest average stress coping attitudes.

The results showed that stress coping attitudes differ significantly according to whether they received religious education or not; the group of those who got religious education were found to have a higher average of stress coping attitudes compared to those who did not have any religious education.

It was found that stress coping attitudes differ significantly according to having religious education in family; those who got religious education in their families have a higher average in stress coping attitudes compared to those who did not get religious education in their families.

The results showed that although there is no meaningful difference between stress coping attitudes of those who had religious education at a Quran course and those who did not, those who received their education at a Quran course were found to have a higher average in stress coping attitudes when compared to those who did not get it at a Quran course.

It was also determined that stress coping attitudes did not differ according to getting religious education from Imam and although there is not a statistically meaningful difference between the two groups, those who received religious education from Imam have a higher average in stress coping attitudes compared to those who did not.

When the responses were anayzied, it was found that stress coping attitudes did not differ according to the religious education they received in Religion and Ethics course at schools. Although there is not statistically any meaningful difference between the two groups, those who had religious education in Religion and Ethics course were found to have a higher average in stress coping attitudes compared to those who did not get religious education in Religion and Ethics course.

It was found that stress coping attitudes differ according to religious education the respondents receive from religious books; those who had religious education from religious books were found to have a higher average in stress coping attitudes compared to those who did not get their religious education from religious books.

The results of the study demonstrated that stress coping attitudes do not differ according to getting religious education they received at Imam Hatip High Schools. Although there is not statistically meaningful difference between the two groups, those who had a religious education at Imam Hatip High Schools have a higher average 
in stress coping attitudes compared to those who did not get religious education at Imam Hatip High Schools.

It was determined that stress coping attitudes do not differ according to the religious education that they received from other sources.

\subsection{Suggestions}

The suggestions developed by considering the findings and analysis of the study are given in the items below:

1) It is necessary that "Religious coping" and "stress coping" topics should be added to the curriculum of the course of "Religion and Ethics".

2) Topics about "religious coping" and "stress coping" should be added to the content of Psychology of Religion course, which is taught at Faculty of Theology that provides education to the students at associate degree and bachelor's degree level.

3) Religious personnel working in Quran courses and mosques should be trained in-service training about stress coping and effective communication skills.

4) Teachers of Religion and Ethics course and Imam Hatip High Schools should be trained in-service training about stress coping and effective communication skills.

\section{References}

Aydın, Ş., \& Örnek, A. Ş. (2006). Kriz ve Stres Yönetimi (Crisis and Stress Management). Ankara: Detay Yayınc1lık.

Baltaş, A., \& Baltaş, Z. (2008). Stres ve Başa Çıkma Yolları (Stress and Coping Ways). İstanbul: Remzi Kitapevi.

Baltaş, Z. (2010). Verimli İş Hayatınin Sirrı Stres (Secrets of Productive working life. Stress). 4. Baskı, İstanbul: Remzi Kitabevi.

Braham, B. J. (2004). Stres Yönetimi (Stress Management). İstanbul: Hayat Yayınları.

Burger, J. M. (2006). Kişilik (Personality). Çeviren: Sarıŏlu, İ.D., İstanbul: Kaknüs Yayınları.

Çayır, C., \& Emhan, A. (2010). Girişimcilerin Stres İle Başedebilmesinde Tinsel Değerlerin Etkisi (Effect of Spiritual Values on Enterpreneuers' Stress Coping Abilities). Atatürk Üniversitesi İktisadi ve İdari Bilimler Dergisi, Cilt: 24, N: 2, Erzurum.

Certel, H. (2008). Din-İletişim İlişskisi ve Dinî İletişim Engelleri (Religion-Communication Relation and Religious Communication Barriers). SDÜ İlâhiyat Fakültesi Dergisi, 2. N: 21, Isparta.

Cirhinlioğlu, F. G. (2010). Din Psikolojisi (Psychology of Religion). Ankara: Nobel Yayınları.

Folkman, S., \& Lazarus, R.S. (1980). An Analysis of Coping in a Middle-Aged Community Sample. Journal of Health and Cocial Psychology, 46, 839-852. http://dx.doi.org/10.2307/2136617

Güvenç, R. (1991). Stres ve Din Eğitimi (Yayınlanmamış Yüksek Lisans Tezi). Selçuk Üniversitesi, Sosyal Bilimler Enstitüsü, Konya.

Hallahmi, B., \& Argyle, M. (1997). The Psychology of Religious Behaviour, Belief and Experience. London: Routledge,

Hökelekli, H. (2008). Psikolojiye Giriş (Introduction to Psychology). Bursa: Düşünce Kitabevi Yayınları.

Karasar, N. (2010). Bilimsel Araştırma Yöntemi (Scientific Research Method). Ankara: Nobel Yayınevi.

Kasapoğlu, A. (2010). Kur'an'a Göre İnkâr ve Bunalım/İnkârcılı̆ıın Ruh Sağlı̆ı̆na Olumsuz Etkileri (Denial and Depression according to Quran /Negative impacts of Denial on spiritual health). İ.Ü. İlahiyat Fakültesi Dergisi Bahar, 2010/1(1) ss.211-235.

Koenig, H. G. (1998). Religious Beliefs and Practices of Hospitalized Medically Ill Older Adults. International Journal of Psychiatry in Medicine, 31.

Kula, M. N. (2005). Bedensel Engellilik ve Dinî Başa Çıkma (Physical Disability and Religious Coping). İstanbul: Dem Yayınları.

Kula, N. (2006). İstenmedik ve Beklenmedik Olaylarla Karşılaşan Bireylere Yönelik Moral ve Manevî Desteğin Önemi. Dinbilimleri Akademik Araştırma Dergisi, VI Number: 2

Lazarus, R. S. (1999). Stress and Emotion. New York: Springer Publishing Company.

Lazarus, R. S., \& Folkman, S. (1984). Stress, Appraisal and Coping. New York: Springer Publishing Company.

Öner, N. (2008). Stres ve Dinî İnanç (Stress and Religious Belief). Ankara: TDV Yayınları.

Özbay, Y. (1993). An Investigation of the Relationship between Adaptational Coping Process and Self-Perceived Negative Feelings on International Students. Ph.D. Thesis, Lubbock, TX: TTU. 
Özbay, Y., \& Şahin, B. (1997). Stresle Başaçıkma Tutumları Envanteri: Geçerlik ve Güvenirlik Çalışması. IV Ulusal Psikolojik Danışma ve Rehberlik Kongresi, A.Ü. Eğitim Bilimleri Fakültesi, Ankara, 1-3 Eylül 1997.

Özcan, M. T. (1985). Ruhî Bunalımlar ve İslâm Ruhiyatı [Spiritual Crisis and Islam Spirit]. Ankara: Güven Mat.

Pargament, K. I. (1997). The Psychology of Religion and Coping. Theory, Research, Practice. New York: Guilford Press.

Pazarl1, O. (1987). Din Psikolojisi [Psychology of Religion]. İstanbul: Remzi Kitapevi.

Peker, H. (1993). Dinî İnanç ve Stres İlişkisi [Relation between Religious Belief and Stress]. Din Öğretimi Dergisi, 38, 53-57.

Peker, H. (2008). Din Psikolojisi [Psychology of Religion]. İstanbul: Çamlıca Yayınları.

Plotnik, R. (2009). Psikolojiye Giriş [Introduction to Psychology]. Çeviren: Tamer Geniş. İstanbul: Kaknüs Yayınları.

Şahin N., \& Durak, A. (1995). Stresle Başa Çıkma Tarzları Ölçeği, Üniversite Öğrencileri İçin Uyarlaması [Stress Coping Styles Scale, Adaptation for University Students]. Türk Psikoloji Dergisi, 10, 56-73.

Şahin, A. (2006). Din Kaynaklı Stres Üzerine Bir Araştırma [A Research on Religious Based Stress]. Selçuk Üniversitesi Ilahiyat Fakültesi Dergisi, 21, 147-180.

Tonta, Y. (2012). Varyans Analizi (ANOVA). http://yunus.hacettepe.edu.tr/ tonta/courses/fall2007/sb5002/sb5002-10-varyans-analizi.pdf

Topuz, İ. (2003). Dinî Gelişim Seviyeleri İle Dinî Başa Çıkma Tutumları Arasındaki İlişki Üzerine Bir Araştırma [A Research on Relation between Religious Development Levels and Religious Coping Attitudes]. Yayınlanmamış Doktora Tezi, Bursa: Sosyal Bilimler Enstitüsü, Uludağ Üniversitesi.

Tutar, H. (2000). Kriz ve Stres Ortamında Yönetim [Management in the Crisis and Stress Environment]. İstanbul: Hayat Yayınları.

Wilkinson, G. (2005). Stres. Çeviren: Ekrem Canbek. İstanbul: Morpa Kültür Yayınları.

Yapıc1, A. (2007). Ruh Să̆lı̆̆l ve Din Psiko-Sosyal Uyum ve Dindarlık [Mental Health and Religious Psycho-Social Cohesion and Religiosity]. Adana: Karahan Kitabevi. 